\title{
PENGEMBANGAN BAHAN AJAR BERBASIS MUATAN LOKAL PADA MATA KULIAH PENDIDIKAN KEWARGANEGARAAN
}

\author{
Emil El Faisal dan Sulkipani \\ Dosen FKIP Universitas Sriwijaya \\ Dosen FKIP Universitas Sriwijaya \\ emil_faisal@ymail.com
}

\begin{abstract}
This research aimed at (1) developing teaching materials based on local content for Civic Education in University; and (2) describing the potential impact of local content on student consciousness on local culture. It was a developmental research. The subject were student registered in Civic Education Course (Mata Kuliah PKn) at History Department. Pilot project was validated through one to one, small group, and field evaluation. The analyzed result indicates that the developed instrument was valid and has potential impact. Supported data shows that the mean score prior to implementation was 6.86 and after implementation was 7.73. In other words, there was an increasing student achievement before and after its implementation. Accordingly, we suggest that this developed material could be implemented widely.
\end{abstract}

Keywords: Materials, Local content, Civic Education

\section{PENDAHULUAN}

Globalisasi merupakan kondisi mendunia yang terjadi di semua lini secara total. Sebagai suatu kenyataan, globalisasi tidak untuk dihindari akan tetapi dibarengi dengan berbagai penyaring yang kuat agar menjadi kekuatan bagi negara. Hal tersebut menjadi sangat penting mengingat globalisasi akan berhadapan langsung dengan muatan lokal negara atau identitas nasional suatu negara. Eksistensi suatu negara pada era globalisasi akan mendapat tantangan dan pengaruh yang besar, baik secara langsung maupun tidak langsung, baik pengaruh positif maupun pengaruh negatif.

Muatan lokal merupakan program kurikuler yang dikembangkan dalam satuan pendidikan di Indonesia. Berdasarkan Permendikbud Nomor 79 Tahun 2014 tentang Muatan Lokal ditegaskan bahwa muatan lokal adalah bahan kajian atau mata pelajaran pada satuan pendidikan yang berisi muatan dan proses pembelajaran tentang potensi dan keunikan lokal. Dalam Pasal 2 dijelaskan bahwa tujuan dari muatan lokal adalah tujuan membekali peserta didik dengan sikap, pengetahuan, dan keterampilan yang diperlukan untuk: mengenal dan mencintai lingkungan alam, sosial, budaya, dan spiritual di daerahnya; serta melestarikan dan mengembangkan keunggulan dan kearifan daerah yang berguna bagi diri dan lingkungan dalam rangka menunjang pembangunan nasional.

Lebih lanjut dinyatakan bahwa nilai-nilai muatan lokal sangat berperan dalam mengukuhkan jati diri bangsa Indonesia sebagai bagian dari masyarakat internasional di tengah peradaban dunia. Eksistensi muatan lokal dapat memberikan kesadaran dan keinginan yang kuat bagi bangsa Indonesia untuk menumbuh kembangkan kecintaan terhadap bangsa dan negara Indonesia (nasionalisme). Untuk mewujudkan hal 
tersebut diperlukan upaya strategis agar pemantapan muatan lokal dapat dilaksanakan secara sistematis dan terarah, sehingga dapat memberikan dampak positif bagi eksistensi negara nasional.

Pendidikan dikatakan sebagai instrumen enkulturasi nilai-nilai budaya yang efektif kepada peserta didik. Karena, melalui pendidikan, pewarisan nilai-nilai luhur budaya bangsa akan berlangsung dalam kondisi yang dinamis dan berdampak secara berkelanjutan sebagai hasil (outcomes) dari proses pendidikan. Seperti yang dijelaskan oleh Tilaar dan Mukhlis (2000) bahwa "pendidikan adalah suatu proses menaburkan benih-benih budaya dan peradaban manusia yang hidup dan dihidupi oleh nilai-nilai atau visi yang berkembang dan dikembangkan dalam suatu masyarakat". Melalui serangkaian kegiatan yang terarah dan sistematis, pendidikan dapat menjadi proses yang memungkinkan terjadinya pengembangan nilai-nilai budaya antar generasi.

Salah satu mata kuliah yang dikembangkan pada satuan pendidikan tinggi di Indonesia adalah Pendidikan Kewarganegaraan. Menurut Azra (Ubaedillah \& Rozak, 2013, p. 15) PKn (civic education) adalah:

Pendidikan yang cakupannya lebih luas dari pendidikan demokrasi dan pendidikan HAM karena mencakup kajian dan pembahasan tentang banyak hal, seperti: pemerintahan, konstitusi, lembaga-lembaga negara demokrasi, rule of law, hak dan kewajiban warga negara, proses demokrasi, partisipasi aktif dan keterlibatan warga negara dalam masyarakat madani, pengetahuan tentang lembaga-lembaga dan sistem yang terdapat dalam pemerintahan, politik, administrasi publik dan sistem hukum, pengetahuan tentang HAM, kewarganegaraan aktif, dan sebagainya.
Sedangkan Menurut Mansoer (Kaelan \& Zubaedi, A., 2007:1-2) pada hakikatnya 'PKn merupakan hasil dari sintesis antara civic education, democracy education, serta citizenship yang berlandaskan pada filsafat Pancasila serta mengandung identitas nasional Indonesia serta materi muatan tentang bela negara'. Berdasarkan hakikat PKn Indonesia yang berbasis Pancasila tersebut Erwin (2011, p. 3) merumuskan bahwa:

PKn di Indonesia merupakan pendidikan kebangsaan dan kewarganegaraan yang berhadapan dengan keberadaan Negara Kesatuan Republik Indonesia (NKRI), demokrasi, Hak Asasi Manusia (HAM) dan cita-cita untuk mewujudkan masyarakat madani Indonesia dengan menggunakan filsafat Pancasila sebagai pisau analisisnya.

Dalam Undang-Undang Nomor 12 Tahun 2012 tentang Pendidikan Tinggi ditegaskan bahwa yang lebih menekankan pada pendekatan psiko-andragogis dan sosiokultural dalam konteks nilai instrumental dan praksis Pancasila dan UUDNRI 1945, serta nilai kontemporer cosmopolitanism. Adapun tujuan utama Pendidikan Kewarganegaraan adalah untuk menumbuhkan wawasan dan kesadaran bernegara, sikap serta perilaku yang cinta tanah air dan bersendikan kebudayaan bangsa (Sumarsono, 2001). Dengan demikian Pendidikan Kewarganegaraan pada dasarnya untuk menumbuh kembangkan kesadaran kebangsaan warga negara Indonesia. Kesadaran tersebut meliputi hak dan kewajiban warga negara dalam upaya menampilkan peran serta dalam pembangunan kehidupan nasional.

Sebagai negara besar yang hidup berBhinneka Tunggal Ika, wujud muatan lokal sebagai identitas nasional akan beragam 
sesuai dengan budaya masing-masing daerah. Misalnya bagi masyarakat Palembang, peranan warga negara dalam bidang politik diwujudkan salah satunya dengan kegiatan rembug-an atau musyawarah untuk mencapai suatu kesepakatan. Bidang sosial budaya diwujudkan dalam berbagai bentuk kegiatan yang dapat memperkuat kebudayaan nasional, seperti kesenian dulmuluk. Bagi masyarakat sunda misalnya, ada bentuk kegiatan udunan yang mencirikan hidup gotong royong untuk memperkuat persatuan dalam masyarakat. Begitu juga dengan muatan lokal daerah-daerah lain di Indonesia yang mencirikan kekayaan budaya bangsa.

Keberhasilan pembelajaran Pendidikan Kewarganegaraan akan mencerminkan peserta didik yang sadar dan menghidupkan nilai-nilai lokal dalam masyarakat. Mereka diharapkan memiliki kesadaran hak dan kewajiban terhadap pembangunan bangsa yang diwujudkan dalam berbagai peran aktif dalam setiap bidang kehidupan. Keberagaman muatan lokal masyarakat merupakan potensi besar bagi dunia pendidikan di Indonesia dengan visi sebagai pewarisan nilai budaya. Karena nilai-nilai luhur budaya bangsa tersebut dapat dikembangkan menjadi sumber belajar berbasis muatan lokal masing-masing daerah. Dalam Undang-Undang Nomor 20 Tahun 2003 tentang Sistem Pendidikan Nasional Pada Pasal 1 ayat (2) dijelaskan bahwa pendidikan nasional adalah pendidikan yang berdasarkan pancasila dan Undang-Undang Dasar Negara Republik Indonesia Tahun 1945 yang berakar pada nilai-nilai agama, kebudayaan nasional indonesia dan tanggap terhadap tuntutan perubahan zaman. Dengan demikian, dapat dikatakan bahwa kekayaan budaya bangsa merupakan salah satu dasar pelaksanaan pendidikan nasional.
Berbagai penelitian mengenai nilai-nilai lokal telah banyak dikaji oleh para peneliti sebelumnya, misalnya Alexon (2010) menunjukkan bahwa Pengembangan Model Pembelajaran Terpadu Berbasis Budaya (MPTBB) terbukti meningkatkan apresiasi siswa terhadap budaya lokal simultan dengan penguasaan materi pelajaran bila dibandingkan dengan model pembelajaran yang selama ini dilakukan.

Berdasarkan uraian tersebut, peneliti tertarik dan dirasa sangat perlu untuk mengkaji mengenai pengembangan bahan ajar pendidikan kewarganegaraan berbasis muatan lokal masyarakat sumatera selatan dan dampak potensial bahan ajar pendidikan kewarganegaraan berbasis muatan lokal tersebut terhadap kesadaran mahasiswa pada budaya lokal.

\section{METODE}

Penelitian ini dilaksanakan di Unit Pelaksana Teknis Mata Kuliah Pengembangan Kepribadian (UPT-MPK) Universitas Sriwijaya dengan masa penelitian selama 1 (satu) tahun. Subjek penelitian yang ditetapkan adalah mahasiswa yang mengambil Mata Kuliah pendidikan Kewarganegaraan pada semester Ganjil 20162017 yang akan ditetapkan dengan random sampling. Subjek yang ditetapkan dalam penelitian ini adalah Mahasiswa Pendidikan Sejarah Semester 1.

Penelitian ini merupakan jenis penelitian dan pengembangan (Research and Development) yang mengacu pada $R \& D$ Cycle Borg and Gall (Sukmadinata, 2007) dan diselaraskan dengan tujuan penelitian yang telah ditetapkan, seperti yang digambarkan secara ringkas pada gambar 1 berikut 
Gambar 1. Prosedur Pengembangan Bahan Ajar Pendidikan Kewarganegaraan Berbasis Muatan Lokal

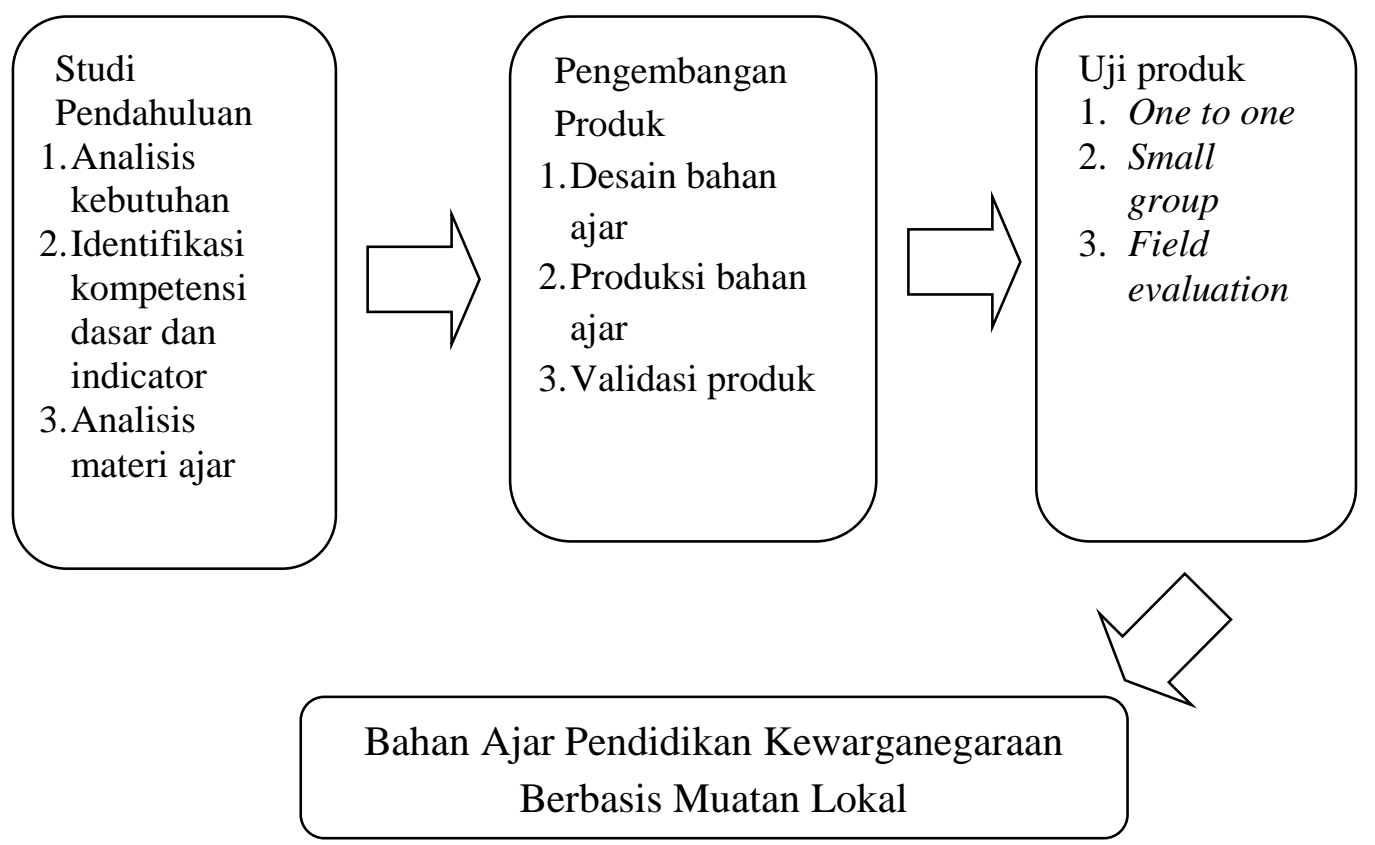

Sumber: Sukmadinata 2007, dengan perubahan

Teknik pengumpulan data yang digunakan dalam penelitian ini adalah dokumentasi, angket, observasi, dan tes. Teknik analisis data yang digunakan dalam penelitian ini adalah analisis data deskriptif kuantitatif. Analisis deskriptif digunakan untuk menganalisis data yang diperoleh melalui studi pendahuluan berupa kompetensi dasar dan indikator pencapaian, serta materi yang akan digunakan untuk dikembangkan sebagai bahan ajar. Selain data hasil studi pendahuluan, data angket yang berkaitan dengan validitas produk juga dianalisis dengan menggunakan analisis deskriptif.
Hasil data angket kemudian dikonversi ke dalam persentase untuk menentukan tanggapan validator terhadap bahan ajar pendidikan kewarganegaraan berbasis muatan lokal yang didasarkan pada kriteria penilaian data persentase menurut Arikunto (2006).

Selanjutnya, data validasi diinterpretasikan dalam bentuk kalimat yang bersifat kualitatif berdasarkan rata-rata data yang diperoleh dan kriteria data masingmasing. Penetapan simpulan yang telah dicapai didasarkan pada kriteria penilaian persentase seperti pada tabel berikut.

Tabel 1. Kriteria Penilaian Data Persentase Untuk Validasi Produk

\begin{tabular}{ccc}
\hline No. & Skor $(\%)$ & Kesimpulan dan tindak lanjut \\
\hline 1 & $80-100$ & Valid/tidak revisi \\
2 & $65-80$ & Cukup valid/revisi (validasi ulang) \\
3 & $\leq 65$ & Tidak valid/revisi (validasi ulang) \\
\hline & & Sumber: Sukmadinata, 2007
\end{tabular}

Analisis kuantitatif dilakukan untuk menganalisis hasil angket dan tes dengan menggunakan analisis nilai gain dan uji $t$ untuk melihat dampak potensial bahan ajar terhadap peningkatan kesadaran dan 
pemahaman mahasiswa terhadap budaya daerah pada saat uji coba bahan ajar.

\section{HASIL DAN PEMBAHASAN}

\section{Studi Pendahuluan}

Dalam proses ini, peneliti berusaha mendapatkan informasi awal dengan cara menganalisis fenomena serta hambatan yang dihadapi oleh mahasiswa dalam mengikuti perkuliahan Pendidikan Kewarganegaraan. Kegiatan ini dilakukan melalui diskusi dengan rekan sejawat yang juga mengajar mata kuliah Pendidikan Kewarganegaraan. Ditarik kesimpulan bahwa mahasiswa tidak memiliki sumber belajar yang banyak dalam pembelajaran mata kuliah kewarganegaraan. Dan juga buku teks yang kebanyakan mereka pakai belum memuat secara khusus mengenai kebudayaan daerah yang memuat muatan lokal daerah tersebut. Padahal nilai-nilai muatan lokal sangat penting diajarkan kepada mahasiswa dalam rangka memberikan mereka informasi agar mampu memahami mengenai ke-khas-an Indonesia yang memiliki banyak keragaman.

Selanjutnya, setelah mengetahui beberapa kendala yang dihadapi dalam proses pembelajaran mata kuliah kewarganegaraan, peneliti melakukan analisis terhadap materi ajar yang akan dibuat dalam bentuk bahan ajar. Pada tahap ini juga dilakukan diskusi dengan para pengajar kewarganegaraan lainnya. Adapun materi yang akan dikembangkan yaitu mengenai identitas nasional. Karena identitas dipandang sebagai materi ajar yang cukup vital dikarenakan mencakup harkat dan jati diri bangsa Indonesia.

Langkah terakhir melakukan analisis materi ajar yang akan dibuat dalam bahan ajar. Tahap ini juga dilakukan dengan diskusi bersama pengajar mata kuliah kewarganegaraan lainnya. Adapun materi yang akan dikembangkan sebagai bahan ajar meliputi pengertian identitas nasional, identitas nasional sebagai karakter bangsa, proses berbangsa dan bernegara, serta politik identitas.

\section{Pengembangan Produk}

\section{a. Desain Produk}

Pada tahapan ini yang dilakukan ialah menentukan beberapa materi yang akan disajikan dalam bahan ajar. Berdasarkan analisis yang telah dilakukan maka diperoleh beberapa materi yang akan dimasukan contoh-contoh muatan lokal pada pembahasannya.

\section{b. Produksi Bahan Ajar}

Merupakan bahan ajar yang masih bersifat prototipe karena belum divalidasi oleh subjek validasi. Selanjutnya bahan ajar diberikan kepada ahli untuk diteliti, jika dalam proses tersebut ditemukan kesalahan maka akan diadakan revisi sampai diperoleh hasil yang valid. Uji validitas produk dilakukan oleh 3 ahli yaitu ahli materi, ahli media serta ahli bahasa.

\section{c. Validasi Produk}

Adapun hasil validasi pertama yang dilakukan oleh validator materi dapat dilihat pada tabel 2 di bawah ini:

Tabel 2 Validasi Materi yang Pertama

\begin{tabular}{|c|c|c|c|c|c|}
\hline \multirow{2}{*}{ No } & \multirow{2}{*}{ Aspek yang Dinilai } & \multicolumn{4}{|c|}{ Skor } \\
\hline & & 4 & 3 & 2 & $\mathbf{1}$ \\
\hline 1. & $\begin{array}{l}\text { Materi sesuai dengan capaian pembelajaran } \\
\text { mata kuliah }\end{array}$ & $\checkmark$ & & & \\
\hline 2. & Sistematika materi sudah sesuai & $\checkmark$ & & & \\
\hline 3. & Kebenaran konsep dalam materi & & $\checkmark$ & & \\
\hline 4. & Contoh yang disajikan sesuai dengan materi & & $\checkmark$ & & \\
\hline
\end{tabular}




\begin{tabular}{|c|c|c|c|c|c|}
\hline \multirow{2}{*}{ No } & \multirow{2}{*}{ Aspek yang Dinilai } & \multicolumn{4}{|c|}{ Skor } \\
\hline & & 4 & 3 & 2 & 1 \\
\hline & Materi mudah dipelajari peserta didik & $\checkmark$ & & & \\
\hline & $\begin{array}{l}\text { Materi yang disajikan menarik bagi peserta } \\
\text { didik }\end{array}$ & $\checkmark$ & & & \\
\hline Tota & Penilaian & & & & \\
\hline Skor & & & & & \\
\hline Kesi & npulan & & & lid & \\
\hline
\end{tabular}

Berdasarkan hasil validasi dari ahli materi, dengan peraturan perundang-undangan yang materi yang terdapat pada bahan ajar ini dikategorikan valid dengan nilai validasi 92\%. Walaupun bahan ajar sudah dinyatakan valid, namun terdapat beberapa komentar dari validator yang membuat bahan ajar ini perlu perbaikan sebelum diujicobakan. Validator berlaku. Validator juga meminta agar pada subbab politik identitas ditambahkan lebih banyak contoh yang berbasis muatan lokal. Adapun hasil validasi kedua yang dilakukan oleh validator materi dapat dilihat pada tabel 3 di bawah ini.

meminta untuk judul mata kuliah disesuaikan

Tabel 3 Validasi Materi yang Kedua

\begin{tabular}{|c|c|c|c|c|c|}
\hline \multirow{2}{*}{ No } & \multirow{2}{*}{ Aspek yang Dinilai } & \multicolumn{4}{|c|}{ Skor } \\
\hline & & 4 & 3 & 2 & 1 \\
\hline & $\begin{array}{l}\text { Materi sesuai dengan capaian pembelajaran } \\
\text { mata kuliah }\end{array}$ & $\checkmark$ & & & \\
\hline & Sistematika materi sudah sesuai & & $\checkmark$ & & \\
\hline 3. & Kebenaran konsep dalam materi & $\checkmark$ & & & \\
\hline 4. & Contoh yang disajikan sesuai dengan materi & $\checkmark$ & & & \\
\hline 5. & Materi mudah dipelajari peserta didik & $\checkmark$ & & & \\
\hline & $\begin{array}{l}\text { Materi yang disajikan menarik bagi peserta } \\
\text { didik }\end{array}$ & $\checkmark$ & & & \\
\hline Tot & Penilaian & & & & \\
\hline Sko & & & & & \\
\hline Kes & npulan & & & & \\
\hline
\end{tabular}

Sumber: data dioleh peneliti, 2016

Berdasarkan hasil validasi dari ahli materi, $\quad 95.8 \%$. Selanjutnya, hasil uji validasi pertama materi yang terdapat pada bahan ajar ini yang dilakukan oleh validator media dapat dikategorikan valid dengan nilai validasi dilihat pada tabel 4 di bawah ini.

Tabel 4 Validasi Media

\begin{tabular}{|c|c|c|c|c|c|}
\hline \multirow{2}{*}{ No } & \multirow{2}{*}{ Aspek yang Dinilai } & \multicolumn{4}{|c|}{ Skor } \\
\hline & & 4 & 3 & 2 & 1 \\
\hline & Kejelasan judul & & $\checkmark$ & & \\
\hline & Sistematika penyajian & & $\checkmark$ & & \\
\hline 3. & Tata letak dan gambar & $\checkmark$ & & & \\
\hline & Kesesuaian ukuran huruf & $\checkmark$ & & & \\
\hline & Kesesuaian gambar dengan materi ajar & $\checkmark$ & & & \\
\hline & $\begin{array}{l}\text { Media yang disajikan menarik bagi peserta } \\
\text { didik }\end{array}$ & $\checkmark$ & & & \\
\hline Tota & Penilaian & & & & \\
\hline Skor & & & & & \\
\hline Kesi & npulan & & & lid & \\
\hline
\end{tabular}


Berdasarkan hasil validasi dari ahli media, maka bahan ajar ini dikategorikan valid dengan nilai validasi $92 \%$. Berdasarkan tabel kriteria nilai validasi maka materi bahan ajar dikatakan valid dan dapat langsung diujicobakan. Selanjutnya, hasil uji validasi pertama yang dilakukan oleh validator bahasa dapat dilihat pada tabel 5

Tabel 5 Validasi Bahasa yang Pertama

\begin{tabular}{|c|c|c|c|c|c|}
\hline \multirow{2}{*}{ No } & \multirow{2}{*}{ Aspek yang Dinilai } & \multicolumn{4}{|c|}{ Skor } \\
\hline & & 4 & 3 & 2 & 1 \\
\hline & Kejelasan bahasa dalam materi & & $\checkmark$ & & \\
\hline 2. & Bahasa mudah dipahami mahasiswa & & $\checkmark$ & & \\
\hline 3. & $\begin{array}{l}\text { Bahasa yang digunakan sesuai kaidah } \\
\text { bahasa Indonesia }\end{array}$ & & & $\checkmark$ & \\
\hline & Penggunaan kalimat & & & $\checkmark$ & \\
\hline & Penggunaan kata dan istilah & & $\checkmark$ & & \\
\hline Tot: & Penilaian & & & 3 & \\
\hline Sko & & & & $5 \%$ & \\
\hline Kes & npulan & & $\mathrm{Cuk}$ & Valid & \\
\hline
\end{tabular}

Sumber: data dioleh peneliti, 2016

Berdasarkan hasil validasi dari ahli bahasa, maka bahan ajar ini dikategorikan cukup valid dengan nilai validasi $65 \%$. Hal itu menunjukan jika bahan ajar ini memerlukan sedikit perbaikan sesuai dengan komentar yang dibuat oleh ahli bahasa. Selanjutnya, hasil uji validasi kedua yang dilakukan oleh validator bahasa dapat dilihat pada tabel 6 di bawah ini

Tabel 6 Validasi Bahasa yang Kedua

\begin{tabular}{|c|c|c|c|c|c|}
\hline \multirow{2}{*}{ No } & \multirow{2}{*}{ Aspek yang Dinilai } & \multicolumn{4}{|c|}{ Skor } \\
\hline & & 4 & 3 & 2 & 1 \\
\hline 1. & Kejelasan bahasa dalam materi & $\checkmark$ & & & \\
\hline 2. & Bahasa mudah dipahami mahasiswa & & $\checkmark$ & & \\
\hline 3. & $\begin{array}{l}\text { Bahasa yang digunakan sesuai kaidah } \\
\text { bahasa Indonesia }\end{array}$ & & $\checkmark$ & & \\
\hline 4. & Penggunaan kalimat & & $\checkmark$ & & \\
\hline & Penggunaan kata dan istilah & & $\checkmark$ & & \\
\hline \multicolumn{2}{|c|}{ Total Penilaian } & \multicolumn{4}{|c|}{16} \\
\hline \multicolumn{2}{|c|}{ Skor } & \multicolumn{4}{|c|}{$80 \%$} \\
\hline \multicolumn{2}{|c|}{ Kesimpulan } & \multicolumn{4}{|c|}{ Valid } \\
\hline
\end{tabular}

Sumber: data dioleh peneliti, 2016

Berdasarkan hasil validasi dari ahli bahasa, diujicobakan di dalam pembelajaran di kelas maka bahan ajar ini dikategorikan cukup valid dengan nilai validasi $80 \%$. Berdasarkan dua untuk melihat efek penggunaannya dalam pemahaman materi ajar. Rekapitulasi hasil uji kali validasi pada materi, media, dan bahasa, maka dapat disimpulkan bahwa bahan ajar ini validasi terhadap bahan ajar ini dapat dilihat pada tabel 7 di bawah ini.

menunjukkan kriteria valid sehingga dapat

Tabel 7 Validasi Bahan Ajar

\begin{tabular}{cccccc}
\hline \multirow{2}{*}{ Validator } & \multicolumn{3}{c}{ Skor (\%) } & \multicolumn{2}{c}{ Kriteria } \\
& Validasi Ke-1 & Validasi Ke-2 & Validasi Ke-1 & Validasi Ke-2 \\
\hline Ahli Materi & 92 & 95.8 & Valid & Valid \\
Ahli Media & 92 & - & Valid & \\
Ahli Bahasa & 65 & 80 & Cukup Valid & Valid \\
\hline
\end{tabular}


Komentar dari ketiga ahli mengenai bahan ajar ini dapat dilihat dalam tabel 8 di bawah ini.

Tabel 8 Komentar Ahli

\begin{tabular}{|c|c|c|c|c|}
\hline No & Nama Validator & Jabatan & Komentar & $\begin{array}{c}\text { Tanggapan } \\
\text { Peneliti }\end{array}$ \\
\hline 1 & Kurnisar, S.Pd, M.H & Ka.Prodi PPKn & $\begin{array}{l}\text { Nama mata } \\
\text { kuliah } \\
\text { disesuaikan } \\
\text { dengan UU } \\
\text { Pendidikan } \\
\text { tinggi. Contoh } \\
\text { materi identitas } \\
\text { disesuaikan } \\
\text { dengan konsep } \\
\text { materi politik } \\
\text { identitas. }\end{array}$ & $\begin{array}{l}\text { Telah } \\
\text { diperbaiki }\end{array}$ \\
\hline 2 & $\begin{array}{l}\text { Dr. Rizwan Djaenuddin, } \\
\text { M.Pd }\end{array}$ & $\begin{array}{l}\text { Wadek } 2 \text { FKIP } \\
\text { (Dosen Prodi } \\
\text { Pendidikan } \\
\text { Ekonomi) }\end{array}$ & $\begin{array}{l}\text { Ditambahkan } \\
\text { beberapa } \\
\text { gambar } \\
\text { sehingga lebih } \\
\text { menarik. }\end{array}$ & $\begin{array}{l}\text { Telah } \\
\text { diperbaiki }\end{array}$ \\
\hline 3 & Rizky Turama, S.Pd, M.A & $\begin{array}{l}\text { Dosen } \\
\text { Pendidikan } \\
\text { Bahasa } \\
\text { Indonesia FKIP } \\
\text { Unsri }\end{array}$ & $\begin{array}{l}\text { Beberapa } \\
\text { kalimat kurang } \\
\text { efektif dan } \\
\text { perlu } \\
\text { disesuaikan } \\
\text { dengan EYD. }\end{array}$ & $\begin{array}{l}\text { Telah } \\
\text { diperbaiki }\end{array}$ \\
\hline
\end{tabular}

Sumber: data dioleh peneliti, 2016

\section{Uji Coba Produk}

Pada tahap ini, peneliti berusaha untuk mendapatkan data sebagai bahan penyempurnaan bahan ajar yang telah disusun. Pelaksanaan uji coba dilakukan dengan berbagai tahap yaitu one to one, small group dan field evaluation.

\section{a. One to one}

Uji coba ini dilakukan dengan mengambil tiga orang mahasiswa pendidikan sejarah kampus Palembang yang memang sedang mengikuti mata kuliah kewarganegaraan. Ketiga orang tersebut memiliki kemampuan yang berbeda dengan kategori tinggi, sedang dan rendah. Peneliti memberikan pembelajaran dengan menggunakan bahan ajar yang telah disusun. Pada akhir pembelajaran, ketiganya diberikan angket. Hasil uji coba dapat dilihat pada tabel 9.

Tabel 9 Rekapitulasi Angket

\begin{tabular}{llcccccccccc}
\hline \multirow{2}{*}{ No } & \multicolumn{1}{c}{ Nama } & $\mathbf{1}$ & $\mathbf{2}$ & $\mathbf{3}$ & $\mathbf{4}$ & $\mathbf{5}$ & $\mathbf{6}$ & $\mathbf{7}$ & $\mathbf{8}$ & $\mathbf{9}$ & $\mathbf{1 0}$ \\
\hline 1 & Nur Fajri Ali & 3 & 3 & 4 & 3 & 4 & 4 & 3 & 3 & 4 & 4 \\
2 & Alif Bahtiar & 3 & 3 & 4 & 3 & 3 & 3 & 3 & 3 & 4 & 4 \\
& Pamulaan & & & & & & & & & & \\
3 & Della Afritaritanti & 4 & 3 & 3 & 3 & 3 & 3 & 3 & 3 & 3 & 3 \\
Total & 10 & 9 & 11 & 9 & 10 & 10 & 9 & 9 & 11 & 11 \\
\hline
\end{tabular}

Berdasarkan hasil angket, maka diperoleh tanggapan sebesar 82,5 \% hal tersebut menunjukkan bahwa bahan ajar ini praktis untuk digunakan dalam pembelajaran mata kuliah 
kewarganegaraan. Pada tahap ini juga dilakukan observasi terhadap pembelajaran di kelas, hasilnya dapat dilihat pada tabel 10

Tabel 10 Hasil Observasi

\begin{tabular}{llcc}
\hline No & \multicolumn{1}{c}{ Indikator } & Jumlah & \% \\
\hline 1. & Mahasiswa memperhatikan penjelasan dosen & 3 & 100 \\
2. $\quad \begin{array}{l}\text { Mahasiswa tidak sibuk dengan aktivitas diluar } \\
\text { proses pembelajaran }\end{array}$ & 3 & 100 \\
3. Mahasiswa mengajukan pertanyaan kepada dosen & 2 & 66,6 \\
4. $\quad \begin{array}{l}\text { Mahasiswa menanggapi pertanyaan yang diajukan } \\
\quad \text { dosen }\end{array}$ & 1 & 33,3 \\
5. $\begin{array}{l}\text { Mahasiswa mengadakan interaksi dengan } \\
\quad \text { mahasiswa lainnya berkaitan dengan proses }\end{array}$ & 1 & 33,3 \\
$\quad$ pembelajaran & 10 & 333,2 \\
Total & & 66,64 \\
Rata-rata
\end{tabular}

Sumber: data dioleh peneliti, 2016

Aktivitas mahasiswa pada tahap uji coba one to one sebesar $66,64 \%$ maka dapat ditarik kesimpulan bahwa mahasiswa termasuk kategori aktif dalam proses uji coba ini.

\section{b. Small Group}

Uji coba tahap ini dilakukan dengan mengambil 6 orang mahasiswa yang memiliki kemampuan berbeda, yaitu kategori rendah, tinggi dan sedang. Hasil angket pada uji coba small group dapat terlihat pada tabel 11 di bawah ini.

Tabel 10. Rekapitulasi Angket

\begin{tabular}{cccccccccccc}
\hline \multirow{2}{*}{ No } & \multirow{2}{*}{ Nama } & $\mathbf{1}$ & $\mathbf{2}$ & $\mathbf{3}$ & $\mathbf{4}$ & $\mathbf{5}$ & $\mathbf{6}$ & $\mathbf{7}$ & $\mathbf{8}$ & $\mathbf{9}$ & $\mathbf{1 0}$ \\
\hline 1 & Dwi Rahmayani & 4 & 3 & 4 & 3 & 4 & 4 & 4 & 3 & 3 & 4 \\
2 & Meidy Anggara & 4 & 4 & 4 & 4 & 3 & 4 & 3 & 3 & 4 & 4 \\
3 & Bayu Suhendry & 4 & 4 & 4 & 4 & 4 & 3 & 4 & 3 & 4 & 4 \\
4 & Reky Gustiandi & 3 & 3 & 3 & 3 & 3 & 3 & 3 & 3 & 2 & 4 \\
5 & Elliya Yuniarti & 4 & 3 & 3 & 4 & 3 & 4 & 3 & 3 & 3 & 4 \\
6 & Ria Amalia & 3 & 3 & 3 & 3 & 3 & 4 & 3 & 3 & 4 & 4 \\
Total & & 22 & 20 & 21 & 21 & 20 & 22 & 20 & 18 & 20 & 24 \\
\hline
\end{tabular}

Berdasarkan hasil angket, maka diperoleh tanggapan sebesar 86,6 \%, hal tersebut menunjukan tanggapan mahasiswa termasuk Sumber: data dioleh peneliti, 2016 kategori sangat baik. Pada tahap ini juga dilakukan observasi terhadap pembelajaran di kelas, hasilnya dapat dilihat pada tabel 11 di bawah ini.

Tabel 11. Hasil Observasi

\begin{tabular}{clcc}
\hline No & \multicolumn{1}{c}{ Indikator } & Jumlah & \% \\
\hline 1. & Mahasiswa memperhatikan penjelasan dosen & 6 & 100 \\
2. & $\begin{array}{l}\text { Mahasiswa tidak sibuk dengan aktivitas diluar } \\
\text { proses pembelajaran }\end{array}$ & 6 & 100 \\
3. & Mahasiswa mengajukan pertanyaan kepada dosen & 2 & 33,3 \\
4. $\begin{array}{l}\text { Mahasiswa menanggapi pertanyaan yang diajukan } \\
\text { dosen }\end{array}$ & 3 & 50 \\
5. Mahasiswa mengadakan interaksi dengan \\
$\begin{array}{l}\text { mahasiswa lainnya berkaitan dengan proses } \\
\text { pembelajaran }\end{array}$ & 2 & 33,3 \\
\hline
\end{tabular}




\begin{tabular}{lrr}
\hline Total & 19 & 316,6 \\
Rata-rata & & 63,32 \\
\hline
\end{tabular}

Sumber: data dioleh peneliti, 2016

Aktivitas mahasiswa pada tahap uji coba bahan ajar yang telah disusun. Hasil uji coba ini sebesar 63,32\% maka dapat ditarik kesimpulan bahwa keaktifan mahasiswa masuk kategori baik.

\section{c. Field Evaluation}

Pada tahapan ini, peneliti menggunakan observasi, tes dan angket dalam rangka melihat efek potensial dan kepraktisan dari tahap ini diuraikan sebagai berikut.

\section{1) Observasi}

Dilakukan dengan menggunakan lembar observer yang menjadi pedoman dalam mengisi indikator yang tampak selama proses pembelajaran. Hasilnya dapat dilihat pada tabel berikut.

Tabel 12. Hasil Observasi

\begin{tabular}{llcc}
\hline No & \multicolumn{1}{c}{ Indikator } & Jumlah & \% \\
\hline 1. & Mahasiswa memperhatikan penjelasan dosen & 30 & 100 \\
2. & $\begin{array}{l}\text { Mahasiswa tidak sibuk dengan aktivitas diluar proses } \\
\text { pembelajaran }\end{array}$ & 27 & 90 \\
3. $\quad \begin{array}{l}\text { Mahasiswa mengajukan pertanyaan kepada dosen } \\
\text { 4. Mahasiswa menanggapi pertanyaan yang diajukan dosen }\end{array}$ & 6 & 20 \\
5. Mahasiswa mengadakan interaksi dengan mahasiswa & 20 & 66,6 \\
$\quad \begin{array}{l}\text { lainnya berkaitan dengan proses pembelajaran } \\
\text { Total }\end{array}$ & 84 & 306.6 \\
Rata-rata & & 61,32 \\
\hline
\end{tabular}

Berdasarkan hasil observasi di atas maka

Sumber: data dioleh peneliti, 2016

diperoleh hasil sebesar $61,32 \%$ sehingga dapat disimpulkan bahwa keaktifan mahasiswa berkategori aktif.

\section{2) Tes}

Di tahap ini diadakan terlebih dahulu tes awal (pretest) sebelum pembelajaran dimulai,

dimaksudkan untuk mengukur kemampuan awal mahasiswa mengenai materi identitas nasional. Selanjutnya posttest diadakan pada akhir pembelajaran. Sebanyak 10 butir soal pilihan ganda yang menjadi soal pada pretest dan posttest. Skor pretest dan posttest mahasiswa dapat dilihat pada tabel berikut.

Tabel 13. Skor Pretest dan Pos test

\begin{tabular}{|c|c|c|c|}
\hline No & Nama & $\begin{array}{c}\text { Nilai Pre } \\
\text { Test }\end{array}$ & $\begin{array}{c}\text { Nilai Post } \\
\text { Test }\end{array}$ \\
\hline 1 & Diwut Setiadi & 6 & 9 \\
\hline 2 & Yunita Afrianti & 8 & 8 \\
\hline 3 & Rahmah Diyah Weryani & 8 & 9 \\
\hline 4 & Alif Bahtiah Pamulaan & 7 & 10 \\
\hline 5 & Jesicha Aprilia & 6 & 6 \\
\hline 6 & Siti Khodijah & 5 & 6 \\
\hline 7 & Khoriatul Khomsatun & 6 & 7 \\
\hline 8 & Dery Tri Andika & 7 & 9 \\
\hline 9 & Hariyani Anggri Putri Sitio & 7 & 7 \\
\hline 10 & M Alfandi Gusti Cahyo & 5 & 8 \\
\hline 11 & Diki Tri Apriansyah P & 8 & 8 \\
\hline 12 & Dwi Rahmayani & 6 & 6 \\
\hline 13 & Mariya Shofiyah & 6 & 6 \\
\hline 14 & Bayu Suhendry & 6 & 9 \\
\hline 15 & Tria Anggun Sari & - & - \\
\hline 16 & Reky Gustiandi & 6 & 7 \\
\hline
\end{tabular}




\begin{tabular}{llcc}
\hline No & \multicolumn{1}{c}{ Nama } & $\begin{array}{c}\text { Nilai Pre } \\
\text { Test }\end{array}$ & $\begin{array}{c}\text { Nilai } \text { Post } \\
\text { Test }\end{array}$ \\
\hline 17 & Irma Sulistia & 6 & 7 \\
18 & Fanny Desliana Sari & 8 & 10 \\
19 & Ade Rismayati & 8 & 7 \\
20 & Meidy Anggara & 8 & 8 \\
21 & Foreka Islamiah & - & - \\
22 & Repi Sundari & 6 & 6 \\
23 & Dwi Kurniawan & - & - \\
24 & Anggie Putri Suryani & 9 & 9 \\
25 & Elliya Yuniarti & 6 & 6 \\
26 & Nur Fajri Ali & 8 & 9 \\
27 & Rizka Maharani & 6 & 6 \\
28 & Kartini Rahmawati & 7 & 8 \\
29 & Maura Rizky Amelia & 7 & 9 \\
30 & Della Afritaritanti & 7 & 6 \\
31 & Muhamad Bagus Soegiarto & 7 & 9 \\
32 & Helayani & 7 & 8 \\
33 & Ria Amalia & 9 & 9 \\
Total & 206 & 232 \\
Rata-rata & 6,86 & 7,73 \\
\hline
\end{tabular}

Sumber: data dioleh peneliti, 2016

Nilai rata-rata pretest dan posttest dapat dilihat pada grafik berikut.

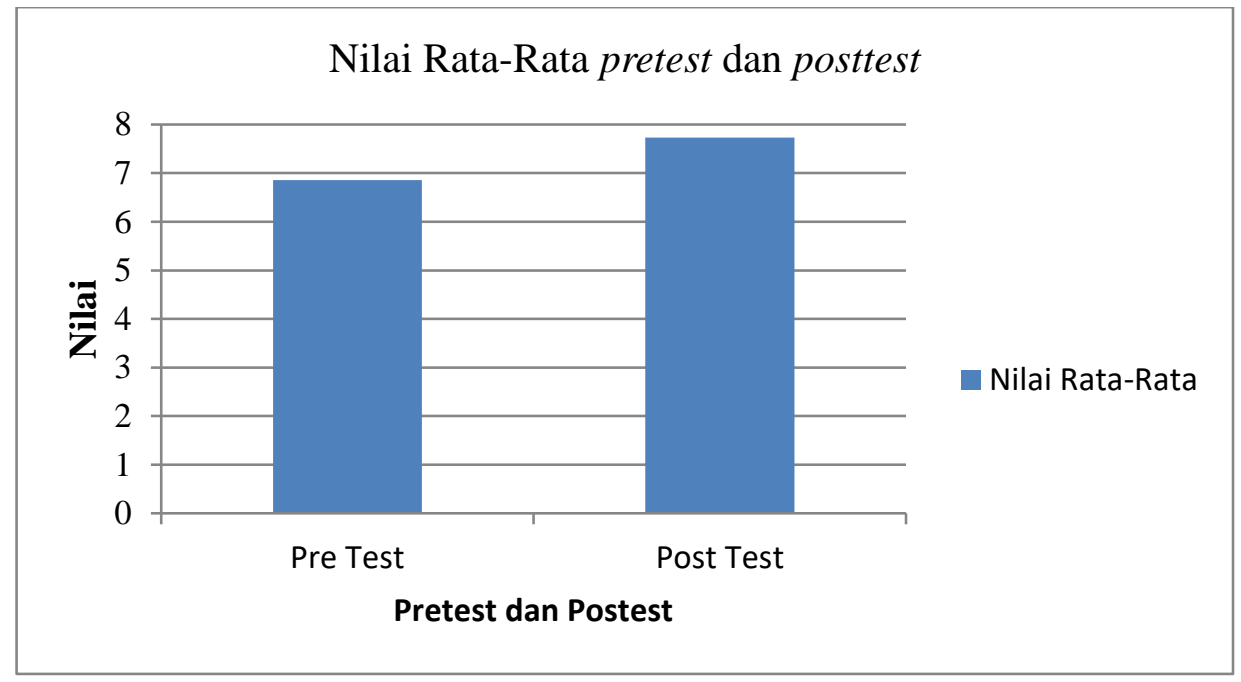

Sumber: data dioleh peneliti, 2016

Berdasarkan grafik di atas, terlihat bahwa rata-rata skor pretest sebesar 6,86. Sedangkan nilai post test rata-rata sebesar 7,73. Maka dapat disimpulkan bahwa terdapat peningkatan sebesar 0,87 dan di dapatkan $\mathrm{N}$ Gain sebesar 0,3 dengan kategori sedang. Hal tersebut menunjukkan bahwa bahan ajar ini memiliki efek potensial terhadap pemahaman mahasiswa pada materi identitas nasional.

3) Angket

Hasil rekapitulasi angket pada tahap ini dapat dilihat pada tabel 14 .

Tabel 14 Rekapitulasi Angket

\begin{tabular}{|c|c|c|c|c|c|c|c|c|c|c|c|}
\hline \multirow{2}{*}{ No } & \multirow{2}{*}{ Nama } & \multicolumn{10}{|c|}{ No Item } \\
\hline & & 1 & 2 & 3 & 4 & 5 & 6 & 7 & 8 & 9 & 10 \\
\hline 1 & Diwut Setiadi & 4 & 4 & 3 & 3 & 3 & 3 & 4 & 3 & 4 & 3 \\
\hline 2 & Yunita Afrianti & 4 & 4 & 4 & 4 & 4 & 4 & 3 & 4 & 4 & 4 \\
\hline 3 & Rahmah Diyah Weryani & 4 & 4 & 3 & 4 & 4 & 3 & 4 & 4 & 3 & 4 \\
\hline
\end{tabular}




\begin{tabular}{|c|c|c|c|c|c|c|c|c|c|c|c|}
\hline \multirow{2}{*}{ No } & \multirow{2}{*}{ Nama } & \multicolumn{10}{|c|}{ No Item } \\
\hline & & $\mathbf{1}$ & 2 & 3 & 4 & 5 & 6 & 7 & 8 & 9 & 10 \\
\hline 4 & Alif Bahtiah Pamulaan & 3 & 3 & 3 & 3 & 4 & 3 & 3 & 3 & 4 & 4 \\
\hline 5 & Jesicha Aprilia & 4 & 2 & 4 & 4 & 4 & 4 & 3 & 3 & 3 & 3 \\
\hline 6 & Siti Khodijah & 4 & 3 & 4 & 4 & 4 & 4 & 3 & 3 & 3 & 3 \\
\hline 7 & Khoriatul Khomsatun & 4 & 3 & 3 & 4 & 4 & 4 & 3 & 3 & 3 & 4 \\
\hline 8 & Dery Tri Andika & 3 & 3 & 3 & 3 & 4 & 3 & 3 & 3 & 3 & 3 \\
\hline 9 & $\begin{array}{l}\text { Hariyani Anggri Putri } \\
\text { Sitio }\end{array}$ & 3 & 3 & 3 & 3 & 4 & 4 & 4 & 3 & 3 & 4 \\
\hline 10 & M Alfandi Gusti Cahyo & 4 & 3 & 3 & 3 & 4 & 4 & 3 & 3 & 3 & 3 \\
\hline 11 & Diki Tri Apriansyah P & 4 & 3 & 4 & 4 & 4 & 3 & 4 & 3 & 4 & 4 \\
\hline 12 & Dwi Rahmayani & 4 & 3 & 4 & 3 & 4 & 3 & 4 & 3 & 4 & 4 \\
\hline 13 & Mariya Shofiyah & 4 & 2 & 3 & 3 & 3 & 3 & 3 & 3 & 3 & 3 \\
\hline 14 & Bayu Suhendry & 3 & 3 & 3 & 3 & 3 & 3 & 3 & 3 & 3 & 3 \\
\hline 15 & Reky Gustiandi & 3 & 3 & 3 & 3 & 3 & 3 & 3 & 3 & 3 & 4 \\
\hline 16 & Irma Sulistia & 4 & 3 & 2 & 4 & 4 & 4 & 4 & 4 & 4 & 3 \\
\hline 17 & Fanny Desliana Sari & 4 & 3 & 4 & 4 & 4 & 4 & 4 & 3 & 4 & 4 \\
\hline 18 & Ade Rismayati & 4 & 3 & 3 & 3 & 3 & 3 & 3 & 3 & 3 & 3 \\
\hline 19 & Meidy Anggara & 4 & 3 & 4 & 4 & 4 & 4 & 4 & 3 & 4 & 4 \\
\hline 20 & Repi Sundari & 4 & 3 & 4 & 4 & 4 & 4 & 4 & 4 & 4 & 4 \\
\hline 21 & Anggie Putri Suryani & 4 & 4 & 4 & 4 & 4 & 4 & 3 & 4 & 3 & 4 \\
\hline 22 & Elliya Yuniarti & 4 & 3 & 3 & 4 & 3 & 3 & 3 & 3 & 3 & 4 \\
\hline 23 & Nur Fajri Ali & 4 & 3 & 4 & 4 & 4 & 4 & 4 & 4 & 4 & 4 \\
\hline 24 & Rizka Maharani & 4 & 4 & 4 & 4 & 4 & 4 & 4 & 4 & 4 & 4 \\
\hline 25 & Kartini Rahmawati & 4 & 3 & 4 & 3 & 3 & 3 & 3 & 3 & 4 & 3 \\
\hline 26 & Maura Rizky Amelia & 4 & 3 & 4 & 4 & 4 & 3 & 4 & 4 & 3 & 4 \\
\hline 27 & Della Afritaritanti & 3 & 2 & 3 & 3 & 3 & 3 & 3 & 3 & 3 & 3 \\
\hline 28 & $\begin{array}{l}\text { Muhamad } \quad \text { Bagus } \\
\text { Soegiarto }\end{array}$ & 3 & 3 & 3 & 4 & 3 & 3 & 3 & 2 & 2 & 3 \\
\hline 29 & Helayani & 4 & 3 & 3 & 3 & 4 & 3 & 3 & 3 & 4 & 4 \\
\hline 30 & Ria Amalia & 3 & 3 & 4 & 3 & 3 & 3 & 3 & 3 & 4 & 4 \\
\hline Total & & 112 & 92 & 103 & 106 & 110 & 103 & 102 & 97 & 103 & 108 \\
\hline
\end{tabular}

Sumber: data dioleh peneliti, 2016

Berdasarkan tabel di atas, rata-rata tanggapan mahasiswa yang menggunakan bahan ajar ini dikategorikan sangat baik dengan nilai sebesar 86,3 \%. Menurut mahasiswa yang menggunakan bahan ajar ini, bahan ajar berbasis muatan lokal sangat membantu dalam mempelajari materi identitas nasional dikarenakan memuat contoh-contoh yang akrab dengan mereka.

\section{Pembahasan}

Dalam melakukan pengembangan bahan ajar berbasis muatan lokal ini terdapat tiga tahapan yang telah dilalui yaitu studi pendahuluan, pengembangan produk dan uji coba produk. Bahan ajar ini sudah melalui tahap expert review yang melibatkan tiga orang ahli yang meliputi ahli materi, ahli media dan ahli bahasa. Setelah dinyatakan valid dan layak di uji coba maka dilakukan dalam tiga tahap yaitu one to one, small grup dan field evaluation.

Sebelum mengembangkan bahan ajar ini sudah barang tentu dilakukan terlebih dahulu analisis yang mendalam mengenai segala hal yang harus dipersiapkan dalam rangka mengembangkan bahan ajar mata kuliah kewarganegaraan agar menjadi lebih bermakna dan berkesan bagi mahasiswa yang mengikuti perkuliahan. Salah satu hal yang dapat meningkatkan pemahaman mengenai materi ialah dengan memberikan contoh nyata yang biasa mereka temui dalam kehidupannya, dengan cara itu mereka dapat 
lebih mengaitkan materi yang dipelajari dengan keseharian.

Setelah prototype bahan ajar telah selesai disusun maka selanjutnya diadakan validasi oleh para validator. Hal ini dilakukan untuk mengetahui validitas bahan ajar. Pada tahapan ini diperoleh rata-rata hasil validasi menurut ahli materi sebesar $92 \%$ pada validasi pertama, kemudian $100 \%$ pada validasi kedua dengan kualitas valid. Kemudian rata-rata 92\% dengan kualitas valid menurut ahli media. Sedangkan dari ahli bahasa rata-rata sebesar $65 \%$ pada validasi pertama dan $75 \%$ pada validasi kedua dengan kualitas cukup valid. Komentar yang diberikan oleh ketiga ahli tersebut menjadi rujukan bagi peneliti sebelum proses uji coba bahan ajar dalam proses pembelajaran. Reigeluth (Warsita, 2008, p. 31) bahwa melalui tahap desain, produksi dan validasi dihasilkan produk yang terjamin kualitasnya dan dapat memenuhi fungsinya untuk mencapai kompetensi pembelajaran yang telah ditetapkan.

Pada tahapan one to one dan small group, mahasiswa telah menggunakan bahan ajar yang sudah melalui tahap validasi oleh validator. Setelah proses pembelajaran, mahasiswa diberikan angket yang harus diisi dalam rangka mengukur pendapat mereka mengenai bahan ajar yang telah disusun tersebut. Terdapat beberapa komentar mengenai bahan ajar tersebut diantaranya istilah dan bahasa yang masih kurang familiar serta masih ada sub materi yang dianggap kurang mendetail dalam penyajiannya.

Tahapan terakhir dari proses pengembangan bahan ajar ini yakni field evaluation. Sebelum mahasiswa mulai masuk materi, diberikan dulu tes awal (pretest) sebagai upaya untuk mengukur pemahaman mereka sebelum menggunakan bahan ajar. Dari rata-rata tes awal diperoleh angka 6,86.
Selanjutnya untuk melakukan perbandingan, diadakan posttest setelah proses pembelajaran berlangsung. Dari rata-rata posttest diperoleh angka 7,73. Berdasarkan hal itu maka terlihat terdapat peningkatan sebesar 0,87 . Jadi dapat disimpulkan bahwa bahan ajar ini memiliki efek potensial dalam rangka membantu mahasiswa untuk dapat lebih memahami materi yang dipelajari.

Setelah melaksanakan posttest maka mahasiswa mengisi lembaran angket yang telah dibagikan. Berdasarkan hasil angket diperoleh tanggapan positif dari mahasiswa mengenai bahan ajar yang telah dikembangkan tersebut dengan perolehan nilai sebesar $86,3 \%$. Selain itu mahasiswa juga menyatakan bahwa bahan ajar sangat menarik dan mudah dipahami sehingga mereka dapat lebih mengerti mengenai materi perkuliahan yang sedang dibahas

Dari beberapa tahapan yang sudah dilalui dalam pengembangan bahan ajar berbasis muatan lokal ini, dapat terlihat bahwa materi yang diajarkan di kelas akan lebih menarik jika dibarengi dengan contoh-contoh nyata apalagi yang ada di sekitar mereka. Dengan hal itu mahasiswa dapat lebih fokus dan memiliki ketertarikan terhadap materi yang diajarkan sehingga dapat meningkatkan pemahaman mereka.

\section{SIMPULAN}

Bahan ajar berbasis muatan lokal yang disusun telah dinyatakan valid oleh semua validator. Dan setelah diuji cobakan dalam tiga tahapan yaitu one to one, small group dan field evaluation maka bahan ajar ini dinyatakan praktis. Selanjutnya bahan ajar ini juga memiliki efek potensial, hal itu dapat terlihat dari meningkatnya hasil belajar mahasiswa setelah diberikan tes pada tahapan field evaluation. Sebelum menggunakan 
bahan ajar dari rata-rata tes awal diperoleh angka 6,86 , selanjutnya dari rata-rata post test diperoleh angka 7,73. Berdasarkan hal itu maka terlihat terdapat peningkatan sebesar 0,87. Maka produk bahan ajar berbasis muatan lokal pada mata kuliah kewarganegaraan ini layak digunakan dalam proses pembelajaran.

\section{UCAPAN TERIMA KASIH}

Pada kesempatan ini penulis menghaturkan ucapan terima kasih kepada Lembaga Penelitian, FKIP, dan UPT MPK Universitas Sriwijaya yang telah memberikan kesempatan dan memfasilitasi penulis dalam melaksanakan penelitian.

\section{DAFTAR PUSTAKA}

Alexon. (2010). Pengembangan model pembelajaran terpadu berbasis budaya untuk meningkatkan apresiasi siswa terhadap budaya lokal. Cakrawala Pendidikan, XXIX(2).

Erwin, M. (2011). Pendidikan kewarganegaraan Republik Indonesia. Bandung: Refika Aditama.

Sukmadinata, N. S. (2007). Metode penelitian pendidikan. Bandung: PT. Remaja Rosdakarya.

Sumarsono, S. (2001). Pendidikan kewarganegaraan. Jakarta: Gramedia Pustaka Utama.

Tilaar, H. A. R., \& Mukhlis. (2000). Pendidikan, kebudayaan, dan masyarakat madani Indonesia. Bandung: PT. Remaja Rosdakarya.

Ubaedillah, A., \& Rozak, A. (2013). Pendidikan kewarga (negara) an; Pancasila, demokrasi, HAM, dan masyarakat madani. Jakarta: Prenada Media Group.

Warsita, B. (2008). Teknologi pembelajaran landasan dan aplikasinya. Jakarta: Rineka Cipta. 